\title{
The Impersonal Personified: Emerson’s Poet
}

Yves GARDES, Université Paris Dauphine

DOI: 10.1080/0950236X.2019.1665925

Emerson's confidence in his vocation as a poet was never defeated throughout his lifetime. Notwithstanding his repeated frustrating efforts to compose poems, he never challenged the thought of being a poet at heart:

I am born a poet, of a low class without a doubt yet a poet. That is my nature \& vocation. My singing be sure is very "husky", $\&$ is for the most part in prose. Still I am a poet. ${ }^{1}$

In this famous 1835 letter to his wife Lydia Jackson, Emerson contrasts the peremptory assertion of his poetic 'nature' and 'vocation' with the practical grounding of his poetic work in the 'low' and in 'prose', thus emphasising the discrepancy between an essential aspiration pertaining to his idealist philosophy and the acknowledgement of incomplete success. Strikingly, a similar comment on his poetic talents is passed in his journals almost thirty years later and provides further insight into Emerson's understanding of his peculiar position as a poet:

I am a bard least of bards [...]; but I am a bard because I stand near them, and apprehend all they utter, and with pure joy hear that which I also would say, and, moreover, I speak interruptedly words and half stanzas which have the like scope and aim: - What I cannot declare, yet cannot all withhold. ${ }^{2}$

While his poetic stutter prevents him from producing full stanzas, Emerson nonetheless entertains the thought of being a poet, since he may 'apprehend' what poets 'utter' freely in verse.

The indeterminacy of Emerson's status as a poet has stirred up much criticism and the question was first settled in the 1970s. In their joint analyses of the poems and the essays, Waggoner, Porter, and Yoder to a lesser extent, struggle to make a case for the poems, frequently turning back to the prose for evidence of poetic talents and concluding that Emerson was a 'failed' poet. ${ }^{3}$ The reason for this verdict is that, more often than not, these authors read the poems against the essay 'The Poet', in which Emerson portrays an ideal poet whose traits and abilities are never all accounted for in the poems. In order to discuss Emerson's status as a poet, this essay adopts a different approach and takes on Sharon Cameron's suggestion that the essay 'The Poet' displays Emerson's bipolar attitude towards his poetic gift. In her essay 'The Way of Life by Abandonment: Emerson's Impersonal', she identifies a 'double voice':

$[\mathrm{O}] \mathrm{n}$ the one hand, the reference for the speaking voice is the unemancipated person who anticipates the poet. But, on the other, the poet being evoked also seemed referenced to the

${ }^{1}$ Ralph Waldo Emerson, The Letters of Ralph Waldo Emerson, eds. Ralph L. Rusk et Eleanor M. Tilton (New York: Columbia University Press, 1939-1995), Vol. 1, p. 435.

${ }^{2}$ Quoted in R. A. Yoder, Emerson and the Orphic Poet in America (Berkeley: University of California Press, 1978), p. $\mathrm{xV}$.

${ }^{3}$ See Hyatt Waggoner, Emerson as Poet (Princeton: Princeton University Press, 1974); David Porter, Emerson and Literary Change (Cambridge: Harvard University Press, 1978); Yoder, Emerson and the Orphic Poet in America. 
subject-position we call Emerson. The one who calls for the poet, who calls the poet forth, is the one who knows enough of bondage not to be wholly or even mainly defined by freedom. Thus, the essay charts two positions and has a double voice. ${ }^{4}$

Sharon Cameron does not mention two voices interlacing in the economy of the same essay, but one double voice, hypothetically and alternately referring to the subject-positions of the poet and of Emerson. In the argument of her essay, Sharon Cameron interprets this negotiation between subject-positions as the speaking voice's failure to perform the impersonal. ${ }^{5}$ Instead, this essay wishes to read this transaction between subject-positions as foundational for Emerson's ambivalent relation to the poet he calls for, and to show how it anticipates instances in which the impersonal voice in the essays refers back to Emerson's ideal poet.

Accordingly, the first section focuses on the discursive logic used to describe the poet at a safe distance from incarnation in speech, to argue that Emerson's poet is presented as a transcendental category and, along with Sharon Cameron, a 'practitioner of impersonality' ${ }^{6}$ The second section turns to a poem which focuses on poetic practice and the crisis the traditional poet experiences in his art - the leap from perception to expression - to suggest that it accounts for the discrepancy between the idealist moment of disembodied contemplation and the materialist struggle of versification. The final section builds on this temporal disjunction to argue that time and acknowledgement of past experience allow for the different subject-positions - Emerson and the poet - to be assumed by the same impersonal voice in the essay 'Experience'.

\section{The practitioner of impersonality}

To present the poet he calls for as a potential practitioner of impersonality, Emerson negates the sentient being of the traditional poet to present the ideal poet as an appearance pertaining to transcendental idealism. In order to do so, he uses a discursive logic of the negative, elsewhere witnessed in his work. In Emerson's Romantic Style, Julie Ellison identifies in 'The American Scholar' the conflict between the two antagonistic classes expressed in 'us' and 'them' - Americans on the one hand, and Europeans on the other - that Emerson stages through the use of the negative. ${ }^{7}$ Similarly, in Emerson and the Conduct of Life, David Robinson underlines that the objective spirit of the photographer or portraitist sets the tone of The Times series, especially in 'The Transcendentalist', the central lecture in which Emerson manipulates the distance between his speaking voice and the transcendentalist he describes. ${ }^{8}$ A similar observation applies to 'The Poet', an essay which extensively draws upon the lecture on the poet in The Times series. Indeed, the prototypical construct of the true poet seems to originate in the negation of the traditional poet in successive movements which show the essence of the poet whom Emerson calls for. First defining the poet by what he is not, Emerson turns the portrait of the poet upside down, in the fashion of

\footnotetext{
${ }^{4}$ Sharon Cameron, 'The Way of Life by Abandonment: Emerson's Impersonal', Critical Inquiry, 25.1 (Autumn 1998), pp. 1-31, p. 27.

5 Cameron, 'The Way of Life by Abandonment'.

${ }^{6}$ Ibid., p. 4.

7 Julie Ellison, Emerson's Romantic Style (Princeton: Princeton University Press, 1984), p. 98.

${ }^{8}$ David Robinson, Emerson and the Conduct of Life. Pragmatism and Ethical Purpose in the Later Work (New York: Cambridge University Press, 1993), p. 55.
} 
the artist, who first outlines shapes in a camera obscura before turning the canvas back up, to paint it from this first sketching.

The incipit of the essay mocks contemporary culture. Emerson both describes and exposes the 'local' cultivation of his contemporaries, whose 'study of rules and particulars, or [...] limited judgement of color or form, [...] is exercised for amusement and show'. The cultural scene is thus turned into a fool's game, a play performed, again and again, with no variation, 'at a safe distance from their own experience'. The doctrines on beauty can only be 'shallow', for the actors who deliver their lines are 'amateurs' who find 'no accurate adjustment between the spirit and the organ'. Conventional poets content themselves with 'a civil and conformed manner of living, and [...] write poems from the fancy', inasmuch as the poetic problem seems to originate from some inadequacy between the form of the poem and its substance.?

In the eponymous essay, the poet is first presented as the negation of the common man: '[The poet] stands among partial men for the complete man, and apprises us not of his wealth, but of the commonwealth' (p. 448). The poet distinguishes himself by his position in society, in which he stands for, that is he represents, the complete man, while his contemporaries are left incomplete. In other words, the poet is not incomplete. Furthermore, the poet instructs his contemporaries not of his own wealth, but of the 'commonwealth'. Also: 'He is isolated among his contemporaries, by truth and by his art, but with this consolation in his pursuits, that they will draw men sooner or later' (p. 448). The repeated preposition 'among' ('He stands among partial men' and 'He is isolated among his contemporaries') both skims through society in general and marks out the poet in particular, thus emphasising the polarisation of society between the poet and common men, beyond seeming social unity.

After presenting the poet as what he is not, Emerson now defines the poet in relation to what common men are not: '[The] great majority of men seem to be minors, who have not yet come into possession of their own, or mutes, who cannot report the conversation they have had with nature' (p. 448, emphasis added). The negative clauses, which describe the common men, should be read in relation to the first negative description of the poet, so that the resulting double negation triggers the first positive traits of the poet in the reader's mind: the poet has come into possession of his own; the poet can report the conversation that he has had with nature. The reader's intuition is even converted to an aspiration further down in the text: 'Every man should be so much an artist, that he could report in conversation what had befallen him' (p. 448, emphasis added) What the poet is, the common man should aspire to be. Through the fate Emerson ascribes him, the poet acquires an identity now formulated in positive terms:

The poet is the person in whom these powers are in balance, the man without impediment, who sees and handles that which others dream of, traverses the whole scale of experience, and is representative of man, in virtue of being the largest power to receive and impart. (p. 448)

The poet's first truly positive depiction should thus be read after a non-synthetic dialectic movement, but should not be seen as a definite conclusion on the poet's identity, for the essay immediately returns to negation.

\footnotetext{
${ }^{9}$ Ralph Waldo Emerson, 'The Poet', in Joel Porte (ed.), Essays and Lectures (New York: The Library of America, 1983), p. 447 (hereafter cited parenthetically in the text with page number).
} 
Indeed, the discursive logic of the essay consists in a constant oscillation between what the poet is not and what common men are not, thus implying what the poet is. In other words, the poet is not, but he is: 'Therefore the poet is not any permissive potentate, but is emperor in his own right'. (p. 449, emphasis added) Or: 'The poet does not wait for the hero or the sage, but [...] he writes primarily what will and must be spoken' (p. 449, emphasis added). The discursive logic of the text constantly oscillates between the negation of what the poet is not and the firm assertion of his defining traits, thus stressing the seemingly permanent discrepancy between the poet and the common man. Following on from this, the text elaborates the paradox inherent in Emerson's description of the poet: the true poet is not accessible, yet he is a representative man who should inspire his contemporaries.

Highlighting an irreparable scission between what the collective intellect conceives of as the poet and the one Emerson wishes for, the essay takes over the myth of Icarus to underline the contrast between the ordinary poet and the true one. In one passage of 'The Poet', Emerson relates the pleasure with which he starts reading a poem, and the hope that his 'chains are to be broken' and that he 'shall mount above these clouds and opaque airs' (p. 451), before realising his expectations will not be met:

Oftener it falls, that this winged man, who will carry me into the heaven, whirls me into the clouds, then leaps and frisks about with me from cloud to cloud, still affirming that he is bound heavenward; and I, being myself a novice, am slow in perceiving that he does not know the way into the heavens, and is merely bent that I should admire his skill to rise, like a fowl or a flying fish, a little way from the ground or the water; but the all-piercing, allfeeding, and ocular air of heaven, that man shall never inhabit. I tumble down again soon into my old nooks, and lead the life of exaggerations as before, and have lost faith in the possibility of any guide who can lead me thither where I would be. (p. 452)

Very much like Icarus flying into the sun, the speaking voice of 'The Poet' aspires to rise to heaven, but the majestic aerial revolutions turn into the small jumps of flying fish, and the speaking ' $\mathrm{I}$ ' is sent back to the condition of an incomplete man. Conversely, in another passage, the wings are no longer symbolic of a vertiginous fall to the low and the common, but rather of the ascent of the poet's soul:

These wings are the beauty of the poet's soul. The songs, thus flying immortal from their mortal parent, are pursued by clamorous flights of censures, which swarm in far greater numbers, and threaten to devour them; but these last are not winged. At the end of a very short leap they fall plump down, and rot, having received from the souls out of which they came no beautiful wings. But the melodies of the poet ascend, and leap, and pierce into the deeps of infinite time. (p. 458)

Through the divergent paths they follow, these two passages point to two diametrically opposed voices. The first one, that of the essay carried by the pronoun 'I', is the voice of the ordinary man whom the reader ought to identify himself to. The second one, that of the poet, offers to make up for Icarus's fate and to reach an elevating power that the first voice cannot claim. Although they seem to confront each other, these two voices never collide, and the conversation between them takes the form of a dialogue of the deaf.

The repeated negations throughout the text not only testify to the degree of abstraction with which Emerson envisions the poet, they also lead the reader to wonder whether such a poet may one day arise, despite Emerson's confidence. Few critics have addressed this issue as precisely as John 
Anderson did in The Liberating Gods: Emerson on Poets and Poetry in 1971. His study led him to conclude that none of the poets mentioned in Emerson's essays qualified for the part - not even Milton, ${ }^{10}$ not even Shakespeare, ${ }^{11}$ not even Whitman. ${ }^{12}$ Emerson's poet thus appears as an appearance pertaining to transcendental idealism which exceeds any living poet, or any who has lived, may he be a man of poetical talents (p. 450) or Shakespeare. On this account, the relation Emerson maintains with Whitman's work very well illustrates the ambiguity of the speaking voice of 'The Poet', a voice imprisoned in the limits of the intellect, and that of the poet, a free and silent voice however palpable. It is indeed worth noting that the regard Emerson first expresses for Whitman in his famous 1855 letter is supported by no later commitment. While Emerson first resorts to superlatives to describe Leaves of Grass as 'the most extraordinary piece of wit \& wisdom that America has yet contributed', ${ }^{13}$ the Sage of Concord does not deem it necessary to include Whitman in his poem anthology Parnassus, published in 1874. In this case, the oscillation between high praise and silence recalls the double voice which reigns over 'The Poet'.

As such, the poet described in the essay qualifies for assuming the role of a 'practitioner of impersonality' insofar as he is extracted from the realm of corporeality and is portrayed as an ideal appearance. Yet, a feeling survives this conclusion and arises from the intuition that the speaking voice in the essay knows a great deal about the poet, or at least, knows enough to talk about him. All the more surprising is that the speaking voice explicitly appears as a 'novice' (p. 452) who lives 'in clouds and opaque airs', and whose 'chains are to be broken' (p. 451), thus questioning the voice's ability to speak of the poet. Does it mean that the speaking voice, in its active search for poetic impersonality, could perform the impersonal in other instances than in the essays? Would this mean that Emerson's poems could qualify as the expression of the ideal poet, against Waggoner, Porter and Yoder's conclusions? In order to address these questions, this article now offers a reading in Emerson's poetry, not so much to confirm the limits of his poetic talents, as to identify the reason why Emerson's expectations in the essay cannot be met.

\section{The vain search for the poet}

'The Discontented Poet: A Masque' is a poem which questions the poetic gift against a background of scepticism. The first version of the poem dates back to 1838, but it was never published, because Emerson added some two hundred lines, changed the title and modified the structure throughout his literary career. With time, 'The Discontented Poem: A Masque' became 'The Poet', a poem divided into two sections entitled 'Fragments on the Poet and the Poetic Gift' and 'Fragments on Nature and Life'. This later version was published in the 1904 centenary edition,

\footnotetext{
10 'But when we adhere to the ideal of the poet, we have our difficulties even with Milton and Homer. Milton is too literary, and Homer too literal and historical' (pp. 465-466).

11 'He rested in their beauty; and never took the step which seemed inevitable to such genius, namely to explore the virtue which resides in these symbols and imparts this power' (Emerson, 'Shakespeare; or, the Poet', Essays and Lectures, p. 725).

12 'Determining Emerson's opinion of Whitman's poetry is the most difficult of all for lack of positive information. Emerson's enthusiasm for Leaves of Grass [...] makes the temptation very great to credit Emerson with a more complete approval of Whitman than he specifically gave' (John Anderson, The Liberating Gods: Emerson on Poets and Poetry [Coral Gables: University of Miami Press, 1971], p. 87).

${ }^{13}$ Ralph Waldo Emerson, Prose and Poetry, eds. Joel Porte and Saundra Morris (New York: Norton, 2001), p. 563.
} 
while the 1838 version only reappeared in the Poetry Notebooks in 1986. It thus seems interesting to read this poem against the essay 'The Poet', since the fate of these two texts - a seminal essay on the one hand and a dismissed poem on the other - mirrors the substance of their message. While 'The Poet' celebrates the new and yet unapproachable poet, 'The Discontented Poet' draws the portrait of a powerless man, who proves unable to express himself adequately. The poem thus underlines the dissatisfaction resulting from poetic practice:

His loves were sharp sharp pains

Outlets to his thoughts were none

A wandering fire within his veins

His soul was smouldered $\&$ undone

A cripple of God, half true, half formed,

And by great sparks Promethan warmed

Constrained by impotence to adjourn

To infinite time his eager turn,

His lot of action from the Urn. ${ }^{14}$

Equating the voice of the poem with Emerson himself, David Porter reads this poem as a moment of crisis in Emerson's career and he concludes that the poem serves as a confession of Emerson's poetic limitations. ${ }^{15}$ The present analysis endeavours to dwell on the details of the very moment of poetic crisis as such, regardless of whom the poet might refer to. Indeed, the poet does not appear in a subject-position in this stanza, the second one of the poem. Instead, he is reified in an objectposition with the enumeration of his immaterial possessions: 'His loves', 'his thoughts', 'His soul', 'his eager turn', 'His lot of action'. Some of them are denied ('His soul was smouldered \& undone') while others are turned into their opposites ('His loves were sharp sharp pains'), but all point to the poet's paralysis and suggest his failure to assert himself as an individual. The repeated adjective 'sharp' both emphasises the pains endured by the poet and signals the primal stuttering of poetic expression that the rest of the stanza confirms with its disruptive syntax.

'The Discontented Poet' questions the very possibility of incarnating the ideal poet of the essay: is it possible to 'stand for' the 'complete man'? The answer is to be found further down in the poem, in another stanza in which the poet voices his hopes of converting the muses' song over from despair:

I see your forms with deep content

I know that ye are excellent;

But will ye stay?

I hear the rustle of wings

Ye meditate what to say

When ye go to quit me forever $\&$ aye. ${ }^{16}$

In the first two lines of this stanza, the poet takes over the responsibility for perceiving forms ('I see') but leaves it to the muses to express them ('Ye meditate what to say'). The distance separating

\footnotetext{
${ }^{14}$ Ralph Waldo Emerson, Collected Poems and Translations, eds. Harold Bloom and Paul Kane (New York: The Library of America, 1994), pp. 371-372.

${ }^{15}$ Porter, Emerson and Literary Change, p. 119.

${ }^{16}$ Emerson, Collected Poems, p. 372.
} 
perception from expression can be measured in terms of doubt, in a question directly addressed to the muses, who, rather than giving forms to express, give them to see. The poet thus seems ordinary and incomplete because he fails to take advantage of his expressive potential while exercising his perceptive powers. Besides, if the muses appease the poet's worries in the following stanza, the sentence they pass on the poet's condition is all the more sceptical: 'From thyself thou canst not flee, / From thyself no more can we'. ${ }^{17}$ If the muses do not give up on the poet, the poet may not give up his incomplete condition and stand for the complete man of the essay. 'The Discontented Poet' is thus confirmed as a traditional poet, a mere man of poetical talents who fails to produce more than single rhymes, naively arranged in a rhyming scheme both aping a Shakespearean sonnet and dismissing it with alternate rhymes and basic couplets (ABABCCDDD).

However, the spectre of 'veins' in the poem ('A wandering fire within his veins / His soul was smouldered \& undone') resonates in the homophone 'vain' of the famous sentence of the essay - 'I look in vain for the poet whom I describe' (p. 465) - so that the vanity of the search for the poet may now be read as the frantic search for a poet who would be asleep inside the essayist. The distance which separates the essayist's voice and that of the poet in their transaction does not so much originate in a spatial measure, but rather in a temporal one, a delay between the acknowledgement of the poet's existence and the claim of this existence by a poetic subject - a delay that Thoreau accounts for in his own poem 'The Poet's Delay':

In vain I see the morning rise,

In vain observe the western blaze,

Who idly look to other skies,

Expecting life by other ways.

Amidst such boundless wealth without,

I only still am poor within,

The birds have sung their summer out,

But still my spring does not begin.

Shall I then wait the autumn wind,

Compelled to seek a milder day,

And leave no curious nest behind,

No woods still echoing to my lay? ${ }^{18}$

The perception of natural phenomena seems hollow ('In vain I see', 'In vain observe') and does not enrich the poet at first glance ('I only still am poor within'), because the immediate experience of natural treasures is sufficient to itself - what need for expression could there be when the natural sight unfurls before the poet? In the time of perception, the experience however spreads through the veins of the poet who, after the delay of a season ('But still my spring does not begin. / Shall I wait the autumn wind'), which is synonymous for privation of experience, will be able to recount this moment through language, and restore the feeling of helplessness which animated the poet in the moment of perception - Apollonian aesthetics is not concomitant with, but consequential to Dionysian intoxication.

\footnotetext{
${ }^{17}$ Ibid., p. 373.

${ }^{18}$ Henry David Thoreau, Collected Essays and Poems, ed. Elizabeth Hall Whiterell (New York: The Library of America, 2001), pp. 535-536.
} 
The discontented poet fails to incarnate the poet advocated in the essay because he fails to exercise his two powers as 'Seer' and 'Namer' at the same time. He is either the 'Seer', or the 'Namer'. Or rather, he is the 'Seer', and only then the 'Namer'. Although he is a poet, he re-enacts the incomplete man and fails to escape his partial nature. As a matter of fact, time arbitrates between the ideal poet and the conventional poet in accordance with Emerson's organic principle (p. 458) that is, what has been perceived requires time to be processed, to be assimilated by the poet, before he can adequately report and express his experience.

Tellingly, 'The Poet' and 'The Discontented Poet' stage the dialogue of the deaf between the speculative voice of the ideal poet and the speaking voice of the essayist. Together, they showcase the paradox of Emerson's transcendental philosophy. On the one hand, the poet, whom Emerson looks for in vain, can never be, for he is a transcendental and immaterial figure. On the other hand, the poet at work confesses the shortcomings of his endeavours to personify the ideal poet, for he fails to incarnate the 'Seer' and the 'Namer' at the same time. Thus, the two voices entertain a dialogue of the deaf: the essay points to the potential expression of the poet while the poet fails to express himself adequately in the poem. Yet Sharon Cameron speaks of a 'double voice', rather than of two different voices, and thus raises the question of a latent interlacing of the two voices. Following on the paradox of Emerson's transcendental philosophy, the next section focuses on instances in which Emerson's ideal poet shows on the surface of his writing.

\section{The poetics of a-logical contiguity}

Since Emerson's poet is an immaterial figure, he is conversely detached from corporeality and sensation. He is therefore virtually unable to acknowledge physical sensations such as pain, for instance. In his study of suffering in American literature, Thomas Constantinesco points to this discrepancy between materialism and idealism in Emerson's work:

Because the soul partakes of the universal and the 'infinite', it remains at once the whole and happily oblivious to the suffering experienced in the material world of bodily encounters, which it discards as nothing more than a series of trivial inconveniences. Pain is ultimately dispensed with as an illusion that 'the soul' sees through and overcomes whenever, in Platonic fashion, it turns away from the world of corporeality to contemplate the ideal. ${ }^{19}$

For the purpose of this analysis, the 'soul' is equated with Emerson's ideal poet, for he is the herald of this extensive and collective soul called the over-soul. It seems that Thomas Constantinesco hints at a possible encounter with what Sharon Cameron calls a 'double voice' or what Joseph Urbas understands as a 'bipolar' Emerson. ${ }^{20}$ Indeed, in his famous essay 'Experience', Emerson relates the intelligibility of grief in the following terms:

The only thing grief has taught me, is to know how shallow it is. [...] Grief too will make us idealists. In the death of my son, now more than two years ago, I seem to have lost a beautiful estate—no more. I cannot get it nearer to me. [...] This calamity [...] does not

\footnotetext{
19 Thomas Constantinesco, 'Emerson's Economy of Pain', in The House of Pain: Suffering, Writing, Thinking in Nineteenth-Century American Literature, unpublished manuscript, forthcoming.

${ }^{20}$ Joseph Urbas, “"Bi-Polar” Emerson: "Nominalist and Realist”, The Pluralist, 8.2 (2013), pp. 78-105.
} 
touch me: some thing which I fancied was part of me, which could not be torn away without tearing me, nor enlarged without enriching me, falls off from me, and leaves no scar. I grieve that grief can teach me nothing. (pp. 472-473)

Grief is here presented as an aporetic experience, which leads the thought of it to a limit and which can only be expressed in the aporetic form of a double bind. Grief, as a form of suffering ('I grieve'), differs from physical pain, which serves nonetheless as an analogical model, and calls it into question. Thinking of grief in terms of pain does allow the persona to think of grief, and does not teach her about grief ('grief can teach me nothing'). The kind of knowledge derived from the experience of grief is one of not knowing, paradoxically enabled by an analogical thought of grief: the trope of the physical wound - the 'scar' - does not allow the persona to get closer to grief, and keeps it at a distance instead.

In her study of Emerson's impersonal, Sharon Cameron partly relies on this forfeit of personal affect to argue that Emerson performs the impersonal: '[His] voice, which is not that of a private person, is in fact public and is engaged in a performance. What is being performed is something like ravishment as a consequence of self-abandonment'. ${ }^{21}$ At the cost of a syllogism, does this mean, Emerson performing the impersonal and his poet being the practitioner of the impersonal, that Emerson is somehow the ideal poet he calls forth? Is it systematically the case and is it possible to argue that the ideal poet is repeatedly personified in Emerson's essays? In her discussion of 'The Divinity School Address', Sharon Cameron asserts that the performance of the impersonal defies systemisation: 'we note the asymmetry of terms by which manifestations of the impersonal defy systemization: they are connected in this discourse, but not logically so. Their originality lies in their deliberately unexplained relations often perceptible as mere contiguity'. ${ }^{22}$ The 'deliberately unexplained relations' can however be accounted for, and require an analysis of what Johannes Voelz calls the 'poetics of a-logical contiguity'. ${ }^{23}$ As a premise to the performance of the impersonal, this poetics is quite similar to Julia Kristeva's considerations on poetic language.

Coming back to 'Experience' and its articulation of grief, the last sentence of the passage surprises the reader because of the contradiction that it contains: 'I grieve that grief can teach me nothing'. The complement clause suggests that the experience of grief is no source for knowledge. Thus, the validity of this very experience is called into question. According to the terms of this clause, the subject, placed in the object-position 'me', proves unable to acknowledge the experience of grief, and so contradicts the main clause and the ability of the subject ' $\mathrm{I}$ ' to acknowledge his own experience of grief. The mind spontaneously corrects this paradox and admits, with Emerson, that the only possible experience of grief is that of its shallowness. 'I' and 'me' thus refer to the same voice and the logic of speech is restored - a-logical contiguity per se. Yet the complement clause does not say 'grief can teach me nothing but one', but 'nothing' indeed, so that 'I' and 'me' may not logically refer to the same voice. Indeed, if 'me' is denied knowledge of grief, how can this same 'me', now placed in the subject-position 'I', acknowledge grief as what it is experiencing? To resolve this paradox, one is encouraged to admit that two different voices are dwelling in the same sentence,

${ }^{21}$ Cameron, 'The Way of Life by Abandonment', p. 17.

${ }^{22}$ Ibid., p. 15.

${ }^{23}$ Johannes Voelz, 'The Recognition of Emerson's Impersonal: Reading Alternatives in Sharon Cameron', in Branka Arsić (ed.), American Impersonal. Essays with Sharon Cameron (New York: Bloomsbury, 2014), p. 85. 
despite the seeming identity of 'me' and 'I'. Yet if one agrees that one of these voices is that of the essay one attributes to Emerson, who does the second voice refer to?

In fact, two different signifying practices are at work: the first signifying practice is that of speech, and the second one is that of utterance, follwing Julia Kristeva's terminology:

One speaks when one judges, that is when one adopts the logic of speech (the Logos), and so negation as an attitude internal to judgement presents itself as a law of excluded middle. One utters when in an approach of negativity (of differentiation) one includes in the act of significance what has no existence in logic (speech), and that is the denied term. ${ }^{24}$

So, utterance achieves this very sort of signifying practice in which a type of negation that does not follow the logic of speech is carried out, when this 'negation' asserts what is denied in a gesture that no longer effects judgement - that would be the gesture of speech. Poetic utterances best exemplify this signifying practice because they effect 'an update of the signifying process, in a gesture which reunites simultaneously the positive and the negative, what exists for speech and what is non-existent for it'. Thus '[the] poetic signified embraces this ambivalent status: it is both (that is, at the same time, and not successively) the concrete and the general'. ${ }^{25}$ Without achieving synthesis, the poetic signified unites both the concrete and the general - Emerson's text says 'I grieve' and not 'I am grieving' - and rejects individualisation, so that the unity of speech splits into two voices which sustain the utterance in a constant tension between the concrete and the general, so that the reader may never clearly identify who 'I' and 'me' refer to, although both pronouns alternately seem to refer to Emerson. And that is precisely what defines the poetic signified: 'it both has and does not have a referent; it does and does not exist, it is being at the same time it is non-being. ${ }^{26}$ If one admits that the voice of 'me' is denied, logic requires that the subject-position of the predicate 'grieve' should be vacant. Yet it is occupied by the subject 'I'. This untimely 'I' fills up the void left by logical speech. With the affirmation 'I grieve', the experiential subject negates the logic of the ideal poet it falls within ('grief can teach me nothing'). This subject is defined by Julia Kristeva as 'zerological', for it is a 'non-subject [which] comes to assume the thought that cancels itself. ${ }^{27}$ In other words, this zerological subject allows Emerson to acknowledge the experience of grief and its shallowness against the logic imposed by his idealist philosophy. This zerological subject can be conceived of as the impersonal personified in a sensuous and experiential being called Emerson.

First presented as an ideal aesthetic figure in 'The Poet', Emerson's poet thus turns into a heteronym, or a conceptual persona, in 'Experience'. If the double voice at work in 'The Poet' proves to be rooted in the imprisoned experiential self, the double voice of 'Experience' is conversely that of an ideal poet, personified in the Emersonian self. The ideal poet is not to be looked for in Emerson's poetry, but in his prose instead, as Emerson himself seemed to suggest. Paradoxically, Emerson's idealist philosophy is the reason why Emerson turns from affect to poetics and personifies the impersonal ideal poet at an untimely moment.

${ }^{24}$ Julia Kristeva, Séméiotikè. Recherches pour une sémianalyse (Paris: Seuil, 1969), p. 189. All translations from Kristeva are mine.

${ }^{25}$ Kristeva, Séméiotikè, p. 190.

${ }^{26}$ Ibid., p. 192.

${ }^{27}$ Ibid., p. 212. 